\title{
Upaya Mereduksi Prokrastinasi Akademik Melalui Konseling Kelompok Melalui Pendekatan Behavioristik Pada Siswa SMK
}

\author{
Puswanti \\ SMP Eka Tjipta Rungau \\ Jl. Jenderal Sudirman km 107 Kalteng, Indonesia \\ Email: ipoezimoet@gmail.com
}

\begin{abstract}
This study aims to determine the effectiveness of group counseling with a behavioristic approach to reducing academic procrastination on vocational students. This type of research is classroom action research, consisting of two cycles and each cycle consisting of three acts. Each cycle begins with the planning, implementation, observation, and reflection. The research subject was determined by purposive sampling of six students with high academic procrastination level criteria. The research instrument used in the form of academic procrastination scale and guidelines for observation. Data analysis using t-test formula. The results showed that the average student academic procrastination 107.33 pretest and posttest mean of 66.5 and $100 \%$ of the students are in the category of academic procrastination low after getting action. It can be concluded that the counseling group with the approach used to reduce the effective behavioristic academic procrastination, vocational students. The results of this study useful for counselors to help students reduce academic procrastination through a counseling group with the behavioristic approach.
\end{abstract}

Keywords: academic procrastination, group counseling, behavioristic

Penelitian ini bertujuan mengetahui keefektifan konseling kelompok dengan pendekatan behavioristik untuk mereduksi prokrastinasi akademik pada siswa SMK. Jenis penelitian yang digunakan adalah penelitian tindakan kelas (Classroom Action Reasearch) yang terdiri dari dua siklus dan setiap siklus terdiri dari tiga kali tindakan. Masing-masing siklus dimulai dengan perencanaan, pelaksanaan, pengamatan, dan refleksi. Subjek penelitian ditentukan dengan purposive sampling yang berjumlah enam siswa dengan kriteria tingkat prokrastinasi akademik tinggi. Instrumen penelitian yang digunakan berupa skala prokrastinasi akademik dan pedoman observasi. Analisis data menggunakan rumus t-test. Hasil penelitian menunjukkan bahwa rerata pretest prokrastinasi akademik siswa 107,33 dan rerata posttest 66,5 serta $100 \%$ siswa berada dalam kategori prokrastinasi akademik rendah setelah mendapatkan tindakan. Dengan demikian dapat disimpulkan bahwa konseling kelompok dengan pendekatan behavioristik efektif digunakan untuk mereduksi prokrastinasi akademik siswa SMK. Hasil penelitian ini bermanfaat bagi konselor untuk membantu siswa mereduksi prokrastinasi akademik melalui konseling kelompok dengan pendekatan behavioristik.

Kata kunci: prokrastinasi akademik, konseling kelompok, behavioristik

\section{Pendahuluan}

Hakikatnya tujuan setiap praktek pendidikan adalah menciptakan manusia yang ideal dan mencapai kehidupan yang lebih baik. Pendidikan mengemban tugas yang mulia, yaitu untuk mencetak generasi yang baik, generasi yang lebih berkebudayaan, dan generasi yang mempunyai kepribadian yang baik. Sekolah merupakan salah satu lembaga pendidikan yang mempunyai tanggung jawab formal kelembagaan dan diatur berdasarkan perundangan dalam pendidikan. Sekolah sebagai pendidikan formal mempunyai peran sebagai pewaris, pemelihara dan sebagai agen pembaharuan. Sebagai upaya mewujudkan peran tersebut, maka dalam kegiatan pendidikan di sekolah melibatkan beberapa unsur di antaranya pendidik dan peserta didik atau siswa.

Pendidik dapat dibedakan menjadi dua, yaitu pendidik menurut kodrat atau orang tua dan pendidik menurut jabatan yaitu guru. Guru memegang peran penting dan strategis dalam pendidikan, terutama dalam proses pembelajaran di sekolah sedangkan peserta didik atau siswa merupakan salah satu komponen pendidikan yang berperan sebagai subjek didik dalam proses pembelajaran. Siswa diarahkan untuk tumbuh dan berkembang secara optimal, memiliki motivasi yang tinggi, prestasi yang gemilang, disiplin dan bertanggung jawab. Demi mewujudkan manusia ideal, siswa harus mengikuti kegiatan belajar 
yang merupakan kegiatan inti dari kesuluruhan proses pendidikan.

Pendidikan di sekolah diharapkan dapat terlaksana dengan sebaik-baiknya, maka dalam proses pendidikan di sekolah tidak hanya mencakup bidang administrasi dan supervisi, serta bidang kurikulum tetapi mengintegrasikan bidang layanan bimbingan dan konseling dalam proses pembelajaran. Pengintegrasian empat bidang tersebut sudah terlaksana tetapi masih ada beberapa kekurangan, yaitu tidak optimalnya pelaksanaan layanan bimbingan dan konseling, misalnya penggunaan metode layanan bimbingan dan konseling yang monoton.

Menurut Mugiarso (2004: 20) bidang layanan bimbingan dan konseling adalah salah satu bidang pelayanan yang perlu dilaksanakan dalam proses pendidikan sebagai bagian dari unsur pedagogis. Peran layanan bimbingan dan konseling meliputi berbagai fungsi dan kegiatan yang mengacu kepada layanan kesiswaan baik secara individu maupun kelompok agar siswa dapat berkembang sesuai dengan bakat, minat, dan potensinya secara optimal. Kebutuhan akan layanan bimbingan dan konseling akan lebih terasa dengan munculnya berbagai permasalahan siswa yang tidak mungkin diselesaikan oleh seorang guru, maka dibutuhkan seorang ahli yang dapat membantu siswa memecahkan masalah yaitu konselor.

Idealnya peran Bimbingan dan Konseling sekolah memberikan bantuan pada permasalahan siswa yang meliputi bidang pribadi, sosial, karir dan belajar, tetapi masih ada beberapa guru bimbingan dan konseling yang masih berpaku pada masalah siswa yang monoton seperti kekerasan atau dalam konteks tindakan yang menyangkut disipliner siswa sehingga perlu adanya berbagai peningkatan terkait mutu dan profesionalisme guru bimbingan dan konseling. Selain itu masih ada beberapa guru bimbingan dan konseling yang masih menggunakan metode yang cenderung monoton dalam memberikan layanan, seperti metode ceramah dengan bercerita terus menerus, sehingga menimbulkan kejenuhan pada siswa dan tujuan layanan tidak tercapai.

Menurut Juntika (2006: 17) layanan bimbingan dan konseling bertujuan untuk membantu siswa dalam berbagai permasalahan yang dihadapi terutama masalah belajar. Patokan nilai kelulusan yang tinggi memunculkan berbagai permasalahan siswa dalam belajar yang tidak hanya membutuhkan campur tangan guru mata pelajaran, tetapi juga guru bimbingan dan konseling. Fakta yang ada di lapangan, dari tahun ke tahun masalah patokan nilai kelulusan menjadi momok mengerikan bagi para siswa, orang tua murid, bahkan guru.

Berbagai usaha telah dilakukan oleh pihak sekolah, terutama guru matapelajaran dan guru bimbingan dan konseling tetapi masih banyak anak yang menemui masalah dalam belajar. Beberapa masalah belajar siswa diantaranya mempersiapkan ujian atau ulangan, memilih cara belajar yang efektif, rendahnya motivasi belajar, cara memusatkan perhatian, dan yang sering menjadi tradisi dari beberapa pelajar baik dari tingkat sekolah dasar, menengah dan perguruan tinggi adalah masalah pengaturan waktu belajar. Pengaturan waktu belajar menjadi salah satu masalah yang akan menimbulkan efek domino bagi siswa maupun mahasiswa. Efek domino dari masalah pengaturan waktu belajar diantaranya siswa menjadi melakukan penundaan seperti penundaan dalam mengumpulkan tugas, menunda berangkat sekolah tepat waktu dan menunda untuk segera masuk kelas setelah bel masuk berbunyi.

Siswa Sekolah Lanjutan Tingkat Atas merupakan siswa yang berada dalam golongan usia remaja, usia mencari identitas dan eksistensi diri. Menurut Damayanti (2012: 54) remaja adalah seorang anak yang berada pada usia tanggung, mereka bukanlah anak kecil yang tidak mengerti apa-apa tetapi juga bukan orang dewasa yang bisa dengan mudah akan membedakan hal mana yang baik dan mana yang berakibat buruk. Perilaku yang tidak sesuai yang dilakukan remaja biasanya didorong oleh keinginan mencari jalan pintas dalam menyelesaikan sesuatu tanpa mendefinisikan secara cermat akibatnya. Perilaku menunda-nunda tugas sekolah merupakan contoh penyesuaian diri yang salah pada remaja di sekolah khususnya dalam hal pembagian waktu. Masih ada beberapa remaja yang tidak bisa mengatur penggunaan waktu yang efektif. Bahkan sebagian remaja tidak terbiasa dengan membuat jadwal belajar harian dan melaksanakannya. Tidak adanya pengaturan penggunaan waktu yang efektif menyebabkan masih ada sebagian remaja yang menunda-nunda untuk segera menyelesaikan tugas sekolah. 
Ferrari, dkk (1995: 3) menyebut kebiasaan menunda-nunda pekerjaan dengan istilah prokrastinasi. Prokrastinasi dapat diartikan sebagai suatu perilaku menunda pekerjaan untuk melakukan sampai waktu atau hari berikutnya. Kecenderungan ini bisa jadi tanpa alasan, atau bisa juga dengan niat baik namun tidak terwujud. Penundaan yang sering terjadi dan dilakukanoleh pelajar adalah penundaan yang dilakukan oleh siswa sebagai bentukbahwa siswa tidak mempunyai perencanaan penggunaan waktu yang efektif.

Fakta dari hasil observasi di SMKN I Kalasan, masih ada beberapa siswa yang mempunyai masalah pengaturan waktu dalam menyelesaikan tugas sekolah. Berdasarkan hasil wawancara dengan guru bidang studi masih ditemukan beberapa kasus prokrastinasi, yaitu pada saat mengumpulkan pekerjaan rumah dengan waktu yang telah ditentukan dari 32 siswa hanya setengah dari jumlah siswa yang mengumpulkan, masih ada lagi setengah dari jumlah siswa yang tidak mengumpulkan tugas pada waktunya dengan mengutarakan berbagai alasan.

Pada dasarnya prokrastinasi akademik yang dilakukan siswa tidak hanya pada tugas. Menurut Milgran (Ferrari 1995) prokrastinasi akademik meliputi penundaan untuk membuat paper atau menulis, penundaan tugas belajar menghadapi ujian, tugas membaca, kinerja tugas akademik, menghadiri pertemuan atau pelajaran, dan kinerja akademik secara keseluruhan. Contoh nyata prokrastinasi akademik lainnya yang terjadi di SMK Negeri I Kalasan adalah masih ada beberapa siswa terlambat masuk sekolah dan mengikuti pelajaran. Beberapa siswa masih ada yang terlambat masuk sekolah dan dengan sengaja melambatkan diri masuk ke ruang kelas untuk mengikuti kegiatan belajar mengajar. Saat bel masuk sudah berbunyi siswa tidak segera masuk kelas, ada beberapa siswa yang masih mengobrol dengan teman-temannya di kantin, mendengarkan musik handphone bersama-sama di depan kelas, dan segera masuk kelas setelah ditegur oleh guru.

Berdasarkan latar belakang masalah yang telah disampaikan penulis, maka perlu adanya usaha yang diharapkan mampu untuk mereduksi prokrastinasi akademik pada siswa, yaitu menggunakan layanan bimbingan dan konseling. Menurut Mugiarso (2004: 23) pengertian
Bimbingan dan Konseling adalah suatu upaya membantu individu melalui proses interaksi untuk mencari solusi pemecahan masalah yang dihadapi oleh individu, dengan menggunakan berbagai teknik, seperti ceramah, diskusi, dan sebagainya. Maka dalam upaya mereduksi prokrastinasi akademik akan digunakan konseling kelompok melaui pendekatan behavioral.

Menurut Winkel dan Hastuti (2002) pendekatan behavioral pertama kali digunakan oleh John D. Krumbols yang berasumsi bahwa setiap tingkah laku dapat dipelajari melalui kematangan dan belajar. Penggunaan Behavioral counseling dengan harapan dalam proses konseling akan menghasilkan counselee behavior. Berdasarkan uraian yang telah disampaikan, maka dalam penelitian ini menggunakan konseling kelompok dengan pendekatan behavioristik diharapkan mampu memunculkan peubahanperubahan perilaku deficit menjadi adjustive terkait dengan prokrastinasi akademik.

Secara operasional, tujuan penelitian ini untuk mengetahui keefektifan konseling kelompok dengan pendekatan behavioristik dalam mereduksi prokrastinasi akademik siswa SMK. Hasil penelitian ini dapat digunakan oleh konselor dalam membantu siswa mereduksi prokrastinasi akademik melalui konseling kelompok dengan pendekatan behavioristik.

\section{Kajian Literatur}

\section{Prokrastinasi Akademik}

Prokrastinasi akademik dapat menyebabkan tujuan belajar tidak dapat tercapai. Burka dan Yuen (2008); Boice (1996); Ferrari dkk (1995: 3) menyebutkan bahwa prokrastinasi dikatakan sebagai suatu perilaku yang tidak efisien dalam penggunaan waktu dan kecenderungan untuk tidak segera memulai pekerjaan ketika menghadapi tugas. Prokrastinasi juga dapat hanya dikatakan sebagai suatu perilaku menunda-nunda tugas, atau menunda memulai menyelesaikan tugas, tetapi bisa juga dikatakan sebagai usaha untuk menghindari tugas sebagai ungkapan rasa tidak suka pada tugas tersebut dan adanya perasaan takut gagal dalam mengerjakan tugas. Menurut Ellis dan Knaus (Ferrari 1995: 72) menyatakan bahwa prokrastinasi juga dapat dikatakan sebagai suatu trait atau kebiasaan seseorang terhadap respon dalam mengerjakan 
tugas karena dilakukan secara berulang-ulang dan sengaja, serta menimbulkan perasaan tidak nyaman yang secara subjektif dirasakan oleh seorang prokrastinator. Selain itu adanya unsur irrasional yang dimiliki oleh pelaku prokrastinasi, yaitu adanya pemikiran bahwa semua tugas harus diselesaikan dengan perfeksionis atau sempurna, sehingga lebih baik menangguhkan sampai hari esok atau tidak mengerjakannya segera karena ditakutkan tidak akan menghasilkan pekerjaan yang maksimal.

Diterangkan juga oleh Spillane dalam bukunya Time Management:Pedoman Praktis Pengelolaan Waktu (2003: 99) bahwa prokrastinasi merupakan kecenderungan untuk menunda-nunda pekerjaan atau tugas bagi setiap orang. Kecenderungan ini bisa tanpa alasan, bisa juga dengan niat baik namun tidak terwujud. Kecenderungan prokrastinasi menjadi salah satu sumber stres, rasa bersalah, dikejar-kejar pekerjaan atau tugas pada saat-saat terakhir yang sudah ditentukan dan rusaknya kerjasama.

Berdasarkan pengertian prokrastinasi yang telah disampaikan olehbeberapa ahli, maka dapat ditarik kesimpulan bahwa prokrastinasi adalah kebiasaan untuk menunda-nunda pekerjaan yang merupakan suatu perilaku yang tidak efektif dalam penggunaan waktu. Menunda-nunda pekerjaan dapat dilakukan dalam berbagai kegiatan, seperti dalam birokrasi, religius, akademik, dan sebagainya. Khusus dalam penelitian ini, akan ditelitimengenai prokrastinasi akademik. Akademik yang dimaksud yaitu kegiatan yang berada pada lingkungan sekolah dan merupakan peraturan yang harus dilaksanakan oleh siswa. Berikut ini akan dijelaskan mengenai pengertian prokrastinasi akademik menurut beberapa ahli.

Pengertian prokrastinasi akademik Menurut Ferrari, dkk (Nugrasanti, 2006: 26) yaitu suatu perilaku untuk menunda-nunda mengerjakan ataupun menyelesaikan tugas-tugas akademik. Perilaku tersebut dapat dilihat pada siswa yang menunda-nunda untuk memulai atau menyelesaikan tugas atau pekerjaan rumah, menyerahkan tugas melewati batas waktu, menunda untuk membaca bahan pelajaran, malas untuk membuat catatan, terlambat masuk kelas dan cenderung lebih suka belajar pada malam terakhir menjelang ujian. Sedangkan menurut Wolter (dalam Nugrasanti, 2006: 29) menyebutkan bahwa prokrastinasi akademik merupakan kegagalan dalam mengerjakan tugas akademik dalam kerangka waktu yang diinginkan atau menunda mengerjakan tugas sampai saat-saat terakhir.

Berdasarkan pengertian prokrastinasi akademik yang telah dipaparkan yaitu bahwa prokrastinasi akademik adalah suatu penundaan yang dilakukan dalam mengerjakan tugas akademik, diantaranya menunda untuk membaca bahan pelajaran, malas untuk membuat catatan, terlambat masuk kelas, dan kecenderungan untuk belajar dengan sistem kebut semalam.

Spesifikasi prokrastinasi akademik disampaikan oleh Millgram(Ferrari 1995: 17) yang menyatakan bahwa: prokrastinasi merupakan perilaku yang spesifik yang meliputi : (1) suatu perilaku yang melibatkan unsur penundaan baik saat memulai maupun menyelesaikan suatu tugas, (2) menghasilakan akibat-akibat yang lebih jauh, seperti keterlambatan menyelesaikan tugas, atau kegagalan dalam mengerjakan tugas, (3) melibatkan suatu tugas yang dipresepsikan oleh pelaku prokrastinasi sebagai suatu tugas yang penting untuk dikerjakan, misalnya tugas kantor, sekolah maupun rumah tangga,(4) menghasilkan keadaan emosional yang tidak menyenangkan, misalnya perasaan cemas, panik,bersalah, marah dan sebagainya.

Berdasarkan spesifikasi perilaku prokrastinasi yang telahdipaparkan, maka spesifikasi prokrastinasi akademik dalam penelitian ini adalah penundaan baik saat memulai maupun menyelesaikan tugas, menghasilkan akibat yang buruk, seperti keterlambatan dan kegagalan dalam menyelesaikan tugas, serta menciptakan keadaan emosional yangtidak menyenangkan, seperti perasaan cemas, panik, bersalah dan marah.

\section{Konseling Kelompok}

Layanan Konseling kelompok pada dasarnya adalah layanankonseling perorangan yang dilaksanakan di dalam suasana kelompok yang berorientasi pada pengembangan individu, pencegahan dan pengentasan masalah, serta diarahkan kepada pemberian kemudahan dalam rangka perkembangan dan pertumbuhan anggota kelompok. Ada beberapapendapat yang sama tetapi disajikan berbeda mengenai pengertian konseling kelompok, di antaranya menurut 
Natawidjaja (2009:7) yang menyebutkan bahwa layanan konseling kelompok pada dasarnya adalah layanan konseling perorangan. Dalam konseling kelompok ada konselor (yang jumlahnya mungkin lebih dari seorang) dan ada klien, yaitu para anggota kelompok (yang jumlahnya paling kurang dua orang).

Pendapat lain disampaikan oleh Winkel dan Hastuti (2004: 225) menjelaskan bahwa konseling kelompok adalah bentuk khusus dari layanan konseling yaitu dengan wawancara antara konselor dengan beberapa orang sekaligus yang tergantung pada kelompok kecil. Menurut Yusuf (2009:83) menyatakan bahwa "konseling kelompok merupakan pemberian layanan konseling yang dilaksanakan untuk membantu siswa memecahkan masalahnya, menangani konflik-konflik antarpribadi dan membantu individuindividu dalam pengembangan kemampuan pribadi mereka (misalnya pengendalian diri, tenggang rasa, dan teposliro). Dalam konseling kelompok masing-masing siswa mengemukakan masalah yang dialaminya, kemudian satu sama lain saling memberikan masukan atau pendapat untuk memecahkan masalah tersebut.

Berdasarkan penjelasan mengenai pengertian konseling kelompok dari beberapa ahli, maka pengertian konseling kelompok adalah merupakan upaya bantuan kepada individu dalam rangka memberikan kemudahan dalam perkembangan dan pertumbuhannya. Penggunaan layanan konseling kelompok dalam penelitian ini didasari pada sifat konseling kelompok selain bersifat pencegahan, tetapi konseling kelompok dapat pula bersifat penyembuhan. Konseling kelompok bersifat penyembuhan sesuai dengan usaha mereduksi prokrastinasi akademik, yaitu memberikan solusi untuk mengurangi tingkat prokrastinasi akademik. selain itu konseling kelompok bersifat pencegahan artinya jika suatu saat nanti siswa melakukan prokrastinasi akademik lagi, siswa tersebut mempunyai pengetahuan bagaimana cara untuk mencegah agar tidak melakukan prokrastinasi kembali.

\section{Konseling Behavioristik}

Istilah terapi atau konseling perilaku merujuk pada penerapanberbagai teknik dan prosedur yang berakar pada berbagai teori belajar. Menurut Natawidjaja (2009: 261) mengartikan bahwa terapi perilaku sebagai penggunaan prinsipprinsip belajar yang disusun berdasarkan eksperimen untuk tujuan mengubah perilaku yang tidak sesuai. Lebih lanjut diterangkan oleh Natawidjaja (2009:259) bahwa pendekatan perilaku sangat populer dalam konseling kelompok karena adanya penekanan terhadap upaya melatih atau mengajar konseli tentang ketrampilan pengelolaan diri yang dapat digunakan untuk mengendalikan kehidupannya, untuk menangani masalah masa kini dan masa yang akan datang, dan untuk mampu berfungsi dengan memadai tanpa terapi yang terus menerus. Lebih lanjut menurut Widaryati (2013) tujuan dari pemberian konseling kelompok adalah untuk membantu individu agar mencapai perkembangan yang optimal, individu dapat belajar menumbuhkan dan meningkatkan kemampuannya dalam kelompok tersebut dan/atau memecahkan permasalahan yang dialami oleh individu yang tergabung dalam anggota kelompok agar dapat mengembangkan dirinya sampai batas kemampuannya

Menurut Gantina dan Wahyuni (2011: 154) menyebutkan bahwakonseling behavioral dikenal juga dengan modifikasi perilaku yang dapat diartikan sebagai tindakan yang bertujuan untuk mengubah perilaku. Modifikasi perilaku dapat pula diartikan sebagai usaha menerapkan prinsipprinsip belajar maupun prinsip-prinsip psikologi hasil eksperimen lain pada perilaku manusia. Jadi behaviorisme berfokus pada bagaimana orangorang belajar dari kondisi-kondisi apa saja yang menentukan tingkah laku mereka.

Berdasarkan pendapat beberapa ahli tentang konselingbehavioristik, maka dapat disimpulkan bahwa konseling behavioristik merupakan suatu proses pemberian bantuan kepada konseli dengan menekankan adanya perubahan tingkahlaku. Sebagai usaha untuk mereduksi prokrastinasi akademik dilakukan dengan cara konseli belajar perilaku baru yaitu tidak lagi menunda menyelesaikan tugas, mempunyai pengaturan penggunaan waktu yang efektif, serta disiplin dan mengeliminasi perilaku yang maladaptif yaitu prokrastinasi akademik, memperkuat serta mempertahankan perilaku yang diinginkan, dan membentuk pola tingkahlaku dengan memberi penguat atau reinforcementyang menyenangkan segera setelah tingkah laku yang diinginkan muncul. Hal tersebut silakukan dengan 
menerapkan tahap-tahap pada konseling behavioristik.

\section{Metode Penelitian}

Penelitian ini merupakan jenis penelitian tindakan kelas (Classroom Action Research) yang terdiri dari dua siklus dan tiap siklus terdiri tiga kali tindakan. Masing-masing siklus dimulai dengan perencanaan (planning), pelaksanaan (acting), pengamatan (observing) dan refleksi (reflecting).

Subjek penelitian yakni enam orang siswa kelas XI Kayu A SMK Negeri Kalasan yang mengalami prokrastinasi akademik tinggi. Adapun instrumen yang digunakan yaitu berupa skala prokrastinasi akademik dan pedoman observasi. Tenik analisis data menggunakan metode analisis deskriptif kuantitatif dengan rumus $t$-test.

\section{Hasil Penelitian Dan Pembahasan}

Sebelum memaparkan hasil penelitian ini, penulis sampaikan terlebih dahulu hipotesis penelitian. Berdasarkan kajian teori dan kerangka pikir yang telah diuraikan sebelumnya, maka hipotesis tindakan yang diajukan oleh peneliti dalam penelitian ini adalah "ada pengurangan tingkat prokrastinasi akademik pada siswa SMKN 1 Kalasan kelas XI Kayu A tahun ajaran 2012/2013 melalui konseling kelompok dengan pendekatan behavioristik".

Dalam hal ini, konseling kelompok terdiri dari 6 orang siswa dengan 1 orang pemimpin kelompok (konselor). Layanan konseling kelompok ini bertujuan untuk mengurangi prokrastinasi akademik siswa dalam belajar. Layanan ini terdiri dari 4 tahapan, yaitu tahap pembentukan, peralihan, kegiatan dan pengakhiran.

Penelitian dimulai dengan kegiatan pre test menggunakan instrumen skala prokrastinasi akademik yang terdiri dari 35 pernyataan. Kemudian, dilakukan tindakan yaitu layanan konseling kelompok behavioristik. Penggolongan variable prokrastinasi akademik sebelum diberi tindakan (pre test) berada pada kategori tinggi, yaitu dengan jumlah frekuensi sebesar $100 \%$. Klasifikasi penggolongan dapat dilihat pada Tabel 1
Tabel 1

Kategori Skor dan Frekuensi Data Prokrastinasi Akademik Sebelum di beri tindakan (pretest)

\begin{tabular}{cccc}
\hline Interval & Frekuensi & F \% & Kategori \\
\hline $114-140$ & - & - & Sangat \\
& & $100 \%$ & Tinggi \\
$96-113$ & 6 & - & Singgi \\
$79-95$ & - & - & Redang \\
$61-78$ & - & - & Sangat \\
$35-60$ & - & $100 \%$ & Rendah \\
Total & 6 & & \\
\hline
\end{tabular}

Adapun klasifikasi skor prokrastinasi akademik sebelum diberi tindakan (pre test) dan setelah diberi tindakan (pos test) dapat dilihat pada Gambar 1.

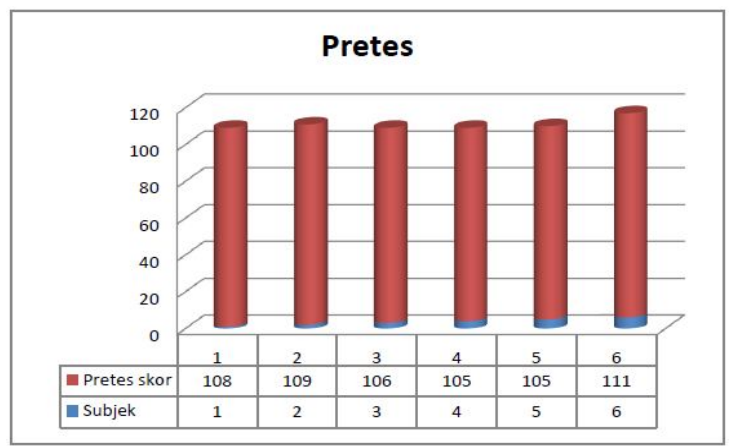

Gambar 1

Kategori Skor Prokrastinasi Akademik Sebelum Diberi Tindakan (Pretest)

Baru kemudian setelah diberikan tindakan (6 tindakan dalam 2 siklus) dilakukan kegiatan post test untuk mengetahui skor prokrastinasi akademik pada subjek pasca tindakan. Pemberian post test juga menggunakan skala prokrastinasi akademik sejumlah 35 pernyataan. Untuk penggolongan variabel prokrastinasi akademik setelah diberi tindakan (post test) dengan menunjukan berada pada kategori rendah, yaitu dengan jumlah frekuensi sebesar $100 \%$. Klasifikasi penggolongan dapat dilihat pada tabel 2 
Tabel 2

Kategori Skor dan Frekuensi Data Prokrastinasi Akademik Setelah Diberi Tindakan (post test)

\begin{tabular}{cccc}
\hline Interval & Frekuensi & F \% & Kategori \\
\hline $114-140$ & - & - & Sangat \\
& & - & Tinggi \\
$96-113$ & - & - & Tinggi \\
$79-95$ & - & $100 \%$ & Redang \\
$61-78$ & 6 & - & Sangat \\
$35-60$ & - & $100 \%$ & Rendah \\
Total & 6 & & \\
\hline
\end{tabular}

Adapun klasifikasi penggolongan skor prokrastinasi akademik setelah diberi tindakan (pos test) dapat dilihat pada Gambar 2 sebagai berikut :

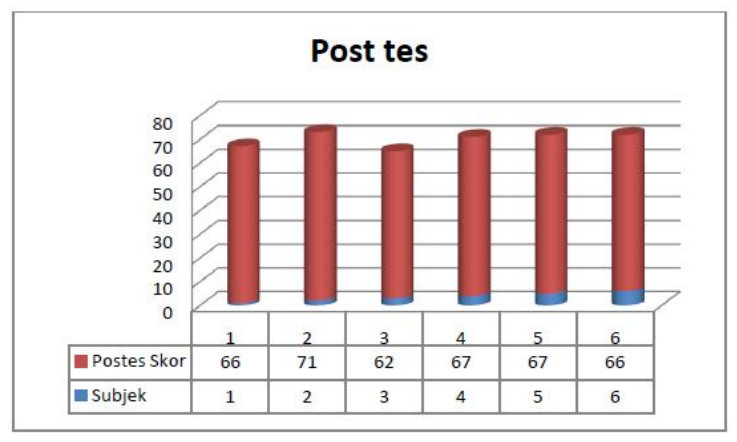

Gambar 2

Kategori Skor Prokrastinasi Akademik Setelah Diberi Tindakan (Postest)

Tindakan yang diberikan dalam penelitian yakni layanan konseling kelompok behavioristik. Dari kedua grafik di atas, maka diperoleh keterangan perbandingan tentang skor prokrastinasi akademik siswa sebelum dan setelah diberi layanan konseling kelompok. Secara rinci dapat dilihat pada Tabel 3 sebagai berikut.
Tabel 3

Deskripsi Skor Variabel Tingkat Prokrastinasi Akademik Sebelum dan Sesudah Tindakan

\begin{tabular}{ccccc}
\hline No & Nama & $\begin{array}{c}\text { Sebelum } \\
\text { Tindakan } \\
\text { (pre test) }\end{array}$ & $\begin{array}{c}\text { Setelah } \\
\text { Tindakan } \\
\text { (post test) }\end{array}$ & $\begin{array}{c}\text { Gain } \\
\text { Skor } \\
\text { (d) }\end{array}$ \\
\hline 1 & AB & 108 & 66 & 42 \\
2 & AS & 109 & 71 & 38 \\
3 & EDM & 106 & 62 & 44 \\
4 & HJS & 105 & 67 & 38 \\
5 & RE & 105 & 67 & 38 \\
6 & SH & 111 & 66 & 45 \\
& Jumlah & 644 & 399 & 245 \\
& Mean & 107.33 & 66.5 & 40.83 \\
\hline
\end{tabular}

Keterangan dalam tabel di atas diperoleh dengan cara melakukan analisis skor skala prokrastinasi akademik pre test dan post test menggunakan bantuan program SPSS. Dimana diperoleh keterangan bahwa skor terbanyak tingkat prokrastinasi akademik sebelum diberi tindakan berada pada kategori tinggi, dimana skor minimum 105 dan skor maksimum 111 dengan mean sebesar 107,33. Setelah diberikan tindakan, skor tingkat prokrastinasi akademik berada pada kategori rendah, dimana skor minimum 62 dan skor maksimum 71 dengan mean sebesar 66,50.

Berdasarkan grafik skor Tingkat Prokrastinasi Akademik sebelum dan sesudah pemberian layanan tersebut dapat dilihat bahwa ada pergeseran garis yang menunjukkan adanya pereduksian skor tingkat prokrastinasi akademik sebelum tindakan (pretest) dan sesudah tindakan (posttest). Sebelum layanan konseling kelompok behavioristik siswa berada pada kategori tinggi sebanyak 6 orang. Setelah diberi layanan konseling kelompok behavioristik terjadi pereduksian tingkat prokrastinasi akademik kategori rendah sebanyak 6 siswa.

Berdasarkan hasil observasi pelaksanaan layanan konseliing kelompok behavioristik yang telah dipaparkan, maka dapat dilihat bahwa setiap pertemuan ada peningkatan skor, pada pertemuan pertama 12,67 dengan skor rata-rata pada kategori cukup yaitu siswa mendengarkan arahan yang disampaikan namun pada keaktifan siswa dalam kegiatan konseling kelompok masih tergolong rendah karena belum ada penyesuaian dan masih canggung. Pada pertemuan ke dua meningkat menjadi 16.67 lalu pada pertemuan ke tiga 
menjadi 18,5 kemudian padapertemuan ke empat menjadi 22,33 begitu selanjutnya pertemuan ke lima 26,5 dan pertemuan ke enam atau terakhir meningkat menjadi 27,17.

Dari hasil observasi dapat dilihat bahwa ada peningkatan aktivitas dalam mengikuti layanan konseling kelompok. Pada siklus I siswa berada pada kategori cukup, siswa belum terbuka, kurang fokus, masih ragu dalam memberikan pendapat dan masukan, belum mampu bekerjasama dengan baik, masih melakukan aktifitas lain dan kurang antusias mengikuti layanan konseling kelompok. Pada siklus II respon siswa dan situasi dalam konseling kelompok sudah berada pada kategori baik. Siswa lebih bersemangat mengikuti layanan, lebih terbuka dalam menceritakan masalahnya, mematuhi arahan peneliti, berani mengeluarkan pendapat dan memberi masukan dalam penyelesaian masalah, interaksi antara anggota fkelompok berjalan dengan baik.

Hipotesis dalam penelitian ini adalah ada penurunan prokrastinasi akademik melalui layanan konseling kelompok dengan pendekatan behavioristik pada siswa kelas XI Kayu A SMK Negeri I Kalasan, Sleman, Yogyakarta. Hipotesi tersebut diuji dengan menggunakan jasa komputer SPSS.

Perhitungan koefisien $\mathrm{t}$ yang menggunakan jasa komputer SPSSmenunjukkan nilai t hitung = 26,574 selanjutnya diadakan pengujian terhadap tabel nilai-nilai distribusi t dengan taraf signifikan $1 \%$ untuk dk $(\mathrm{N}-1)=6-1=5$ adalah 4,032 Hal ini menunjukkan bahwa nilai t hitung lebih besar dari t tabel yaitu 26,574>4,032 atau nilai $\mathrm{p}=000$ (p <0,01). Tabel distribusi nilai $\mathrm{t}$ dapat dilihat pada. Uji t merupakan uji pembanding sebelum pemberian tindakan dengan layanan konseling kelompok maean 107,33 dan sesudah diberi tindakan 66,5 maka dapat disimpulka ada perbedaan signifikan tingkat prkrastinasi akademik anatara sebelum dan sesudah diberi tindakan layanan konseling kelompok. Perbedaan signifikan tersebut menunjukkan adanya pereduksian tingkat prokrastinasi akademik siswa setelah diberikan layanan konseling kelompok behavioristik.

Dengan demikian maka hipotesis nihil (Ho) yang diajukan berbunyi "tidak ada penurunan tingkat prokrastinasi akademik melalui layanan konseling kelompok dengan pendektan behavioristik pada siswa kelas XI A SMK Negeri
I Kalasan, Sleman, Yogyakarta tahun ajaran 2012/2013” Ditolak. Sedangkan hipotesis alternatif (Ha) yang diajukan “Ada penurunan tingkat prokrastinasi akademik melalui layanan konseling kelompok dengan pendekatan behavioristik pada siswa kelas XI Kayu A SMK Negeri I Kalasan, Sleman, Yogyakarta diterima sehingga teruji kebenaranya.

Berdasarkan hasil penelitian yang telah dipaparkan, maka dapatdisimpulkan bahwa “ ada pengurangan tingkat prokrastinasi akademik melalui layanan konseling kelompok dengan pendekatan behavioristik pada siswa kelas XI Kayu A SMK Negeri I Kalasan, Sleman, Yogyakarta.

Hasil analisis data menunjukkan bahwa pelaksanaan layanan konseling kelompok dapat mereduksi prokrastinasi akademik pada siswa kelas XI Kayu A SMK Negeri I Kalasan, Sleman, Yogyakarta. Menurunnya tingkat prokrastinasi akademik siswa tersebut dapat

diketahui dari hasil observasi dan pemberian skala prokrastinasi akademikpretest dan postest serta hasil mean yang menurun saat pre test dan post test. Menurunnya tingkat prokrastinasi akademik berdasarkan pemberian skala prokrastinasi akademik pretest dan postest menunjukkan sebelum diberi tindakan berada pada kategori tinggi yaitu dengan jumlah frekuensi 6 sebesar 100\%. Setelah diberi tindakan berada pada kategori rendah dengan frekuensi 6 sebesar $100 \%$.

Menurunnya tingkat prokrastinasi akademik berdasarkan hasil observasi diketahui bahwa ada peningkatan respon dan aktivitas siswa padasetiap siklus tindakan. Pada siklus I siswa terlihat kurang antusias dalm mengikuti layanan, kurang berani mengeluarkan pendapat, siswa belum bisa bekerjasama dan berinteraksi dengan baik, sehingga layanan belum berjalan dengan lancar. Pada siklus II siswa sudah mulai antusias dalam mengikuti layanan, berani mnegeluarkan pendapat, memberi masukan cara penyelesai masalah, mendengarkan arahan yang diberikan peneliti, terbuka dalam mengungkapkan masalah, dapat berinteraksi dan bekerjasama dengan baik sehingga suasana layanan mulai berjalan dengan lancar, dan siswa sudah memahami pentingnya mereduksi prokrastinasi akademik. Setelah melihat hasil observasi yang dicapai setiap siswa dalam setiap siklus tindakan, maka terdapat 
penurunan tingkat prokrastinasi akademik maka hipotesis yang diajukan dalam penelitian ini teruji kebenaranya. Hal ini menunjukan bahwa prokrastinasi akademik dapat direduksi melalui layanan konseling kelompok dengan pendekatan behavioristik.

\section{Simpulan}

Berdasarkan hasil yang diperoleh dari analisis data dan pembahasan, maka dapat disimpulkan bahwa layanan konseling kelompok dengan pendekatan behavioristik efektif untuk mereduksi prokrastinasi akademik pada siswa kelas XI Kayu A SMK Negeri I Kalasan. Bagi guru bimbingan dan konseling, diharapkan dapat memberikan layanan konseling kelompok pendekatan behavioristik kepada siswa yang mengalami prokrastinasi akademik secara lebih konsisten. Hasil penelitian ini bermanfaat bagi konselor untuk membantu siswa mereduksi prokrastinasi akademik melalui konseling kelompok dengan pendekatan behavioristik.

\section{Referensi}

Boice, Robert. 1996. Procrastination and Blocking: A Novel, Practical Approach. USA: Praeger Publishers.

Burka dan Yuen. 2008. Procrastination: Why You Do It, What To Do About It Now. Cambridge: Da Capo Press.

Damayanti, Nidya. 2012. Panduan Bimbingan dan Konseling. Yogyakarta:Araska

Ferrari J. R, dkk. (1995). Procrastination and Task Avoidance. New York and London: Plenum Press.
Juntika, Ahmad. 2006. Bimbingan dan Konseling dalam Berbagai Latar Kehidupan. Bandung: Refika Aditama

Komalasari, Gantina dan Eka Wahyuni. 2011. Teori dan Teknik Konseling. Jakarta: PT Indeks.

Mugiarso, Heru,dkk. 2004. Bimbingan dan Konseling. Semarang: UPT UNNES Press.

Natawidjaja, Rochman. 2009. Konseling Kelompok Konsep Dasar dan Pendekatan. Bandung: Rizqi Press.

Nugrasanti, Reni. 2006. Locus of Control dan Prokrastinasi Akademik Mahasiswa; Jurnal Provitae 2 No 1, Mei 2006. Jakarta: Yayasan OborIndonesia.

Riduwan. 2008. Skala Pengujuran Variabelvariabel Penelitian. Bandung: Alfabeta.

Spillane, J, James. 2003. Time Management; Pedoman Praktis Pengelolaan Waktu. Yogyakarta: Kanisius.

Suharsimi, Arikunto dan Cepi Safrudin Abdul Jabar. 2007. Evaluasi Program Pendidikan. Jakarta: Bumi Aksara.

Wibowo, Mungin Eddy. 2005. Konseling Kelompok Perkembangan. Semarang: UPT UNNES Press.

Widaryati. Sri. 2013. Efektivitas Pengaruh Konseling Kelompok Terhadap Efikasi Diri Siswa SMA Negeri 1 Pengasih Tahun Pelajaran 2012/2013. PSIKOPEDAGOGIA Bimbingan dan Konseling, 2(2): 25-31.

Wiriatmaja, Rochiati. 2005. Metodologi Penelitian Tindakan Kelas. Bandung: Rosda. Yusuf, Syamsu. 2009. Program Bimbingan dan Konseling di Sekolah. Bandung: Rizqi Perss. 